\title{
Diacylglycerol Synthesis De Novo from Glucose by Pancreatic Islets Isolated from Rats and Humans
}

\author{
Bryan A. Wolf, Richard A. Easom, Michael L. McDaniel, and John Turk \\ Division of Laboratory Medicine, Departments of Internal Medicine and Pathology, \\ Washington University School of Medicine, St. Louis, Missouri 63110
}

\begin{abstract}
Recent evidence has suggested that pancreatic islets isolated from rats synthesize 1,2-diacyl-sn-glycerol (DAG) de novo from glucose and that this process may constitute the longsought link between the metabolism of glucose and the induction of insulin secretion. The cell-permeant diacylglycerol 1oleoyl-2-acetyl-sn-glycerol $(200 \mu \mathrm{M})$ has been found here to amplify both the first and second phases of insulin secretion from perifused human islets. Measurements of the mass of endogenous DAG in human pancreatic islets by enzymatic and by mass spectrometric methods indicate that levels of $200 \mu \mathrm{M}$ may be achieved under physiologic conditions. Conversion of $\left[{ }^{14} \mathrm{C}\right] g l u c o s e$ to $\left[{ }^{14} \mathrm{C}\right] \mathrm{DAG}$ has been demonstrated here to occur within $60 \mathrm{~s}$ of exposure of rat and human islets to stimulatory concentrations of glucose. This process has been found to be a quantitatively minor contributor to the total islet DAG mass after acute stimulation with glucose, however, and glucose has been found not to induce a rise in total islet DAG content within $20 \mathrm{~min}$ of induction of insulin secretion. In contrast to the case with rodent islets, two pharmacologic inhibitors of DAG-induced activation of protein kinase $C$ (staurosporine and sphingosine) have been found not to influence glucose-induced insulin secretion from isolated human islets. These findings indicate that de novo synthesis of DAG from glucose does not participate in acute signal-response coupling in islets. ( $J$. Clin. Invest. 1990. 85:482-490.) diacylglycerol • insulin • pancreatic islets
\end{abstract}

\section{Introduction}

The beta cells of pancreatic islets maintain the blood glucose concentration within a narrow range by modulating their insulin secretory rate in response to the glucose levels in blood (1). This glucose sensor function appears to be intrinsic to islets, since islets isolated from human or rodent pancreata retain the ability to augment their insulin secretory rate in response to increases in the glucose concentration in the medium bathing them (2-9). Some insulin secretagogues, such as muscarinic agonists, induce insulin secretion via interaction with a beta cell plasma membrane receptor $(5,8)$. Glucose and

Address reprint requests to Dr. Turk, Division of Laboratory Medicine, Washington University School of Medicine, Box 81 18, 660 South Euclid Avenue, St. Louis, MO 63110.

Received for publication 17 July 1989 and in revised form 15 September 1989 .

J. Clin. Invest.

(c) The American Society for Clinical Investigation, Inc.

0021-9738/90/02/0482/09 \$2.00

Volume 85, February 1990, 482-490 some other carbohydrates, such as mannose, must be metabolized by islets in order to induce insulin secretion and are therefore designated "fuel secretagogues" (2-6). The biochemical mechanisms whereby islet glucose recognition is coupled to insulin secretion have been intensively studied because the disease type II diabetes mellitus is characterized by a relatively selective defect in glucose-induced insulin secretion despite nearly normal secretory responses to some other insulin secretagogues (10).

Recent interest has focused on the possibility that 1,2-diacyl-sn-glycerol (DAG) ${ }^{1}$ synthesized de novo from glucose in beta cells might constitute the metabolic signal derived from glucose that initiates insulin secretion, possibly by activation of protein kinase $\mathrm{C}(11-13)$. This hypothesis is based primarily on observations with rat islets, including the facts that exogenous diacylglycerol $(13,14)$ and phorbol esters (15) augment insulin secretion, that glucose induces the accumulation of a palmitate-rich 1,2-diacyl-sn-glycerol in islets $(12,13)$, and that pharmacologic inhibitors of protein kinase $C$ suppress glucose-induced insulin secretion $(16,17)$. Qualitative radiochemical studies have demonstrated that rodent islets convert glucose, in part, to diacylglycerol $(12,18-21)$ via the glycolytic intermediate dihydroxyacetone-phosphate (18), which is one of the triose phosphates (22). The attractiveness of the diacylglycerol hypothesis of insulin secretion is enhanced by the fact that all known carbohydrate insulin secretagogues, including glucose and mannose, are converted by islets to the triose phosphates $(4,6)$. The closely related compounds lactate and pyruvate are not converted to triose phosphates by islets and do not induce insulin secretion, although these compounds are readily oxidized by islets (6).

To evaluate this hypothesis further, we have determined the quantitative significance and time course of diacylglycerol accumulation via de novo synthesis from glucose in rat and in human islets, the content of palmitate and other fatty acyl substituents in human islet diacylglycerol under basal conditions and after stimulation with glucose, and the influence of exogenous diacylglycerol and of pharmacologic inhibitors of protein kinase $\mathrm{C}$ on insulin secretion from human islets.

\section{Methods}

\section{Materials}

Male Sprague-Dawley rats (180-200 g body wt) were purchased from Sasco (O'Fallon, MO). Collagenase (CLS IV) was obtained from Boehringer Mannheim, Inc. (Indianapolis, IN). Tissue culture medium (CMRL-1066), penicillin, streptomycin, Hanks' buffer, heat-in-

1. Abbreviations used in this paper: DAG, 1,2-diacyl-sn-glycerol; GC, gas chromatography; MS, mass spectrometry; NICI, negative ionchemical ionization; OAG, 1-oleoyl-2-acetyl-sn-glycerol; PFBE, pentafluorbenzyl ester. 
activated fetal bovine serum, and L-glutamine were from Gibco Laboratories (Grand Island, NY). Pentex bovine serum albumin (fatty acid free, Fraction V) was obtained from Miles Laboratories (Elkhart, IN). Rodent chow 5001 was purchased from Ralston Purina Co. (St. Louis, MO). Standard fatty acids were obtained from NuChek Prep (Elysian, MN). Cardiolipin and 1-oleoyl-2-acetyl-sn-glycerol were obtained from Avanti Polar Lipids (Elkham, AL) and octyl- $\beta$-D-glucoside was obtained from Calbiochem-Behring Diagnostics (La Jolla, CA). Standard phospholipids were from Sigma Chemical (St. Louis, MO) or from Serdary Research Laboratories (London, Ontario, Canada). Dglucose was purchased from the National Bureau of Standards (Washington, $\mathrm{DC}$ ). Tetramethylammonium hydroxide and $N, N$-dimethylacetamide were from EM Science (Cherry Hill, NJ). Pentafluorobenzyl bromide was purchased from Pierce Chemical Co. (Rockford, IL). Diacylglycerol kinase from Escherichia coli was purchased from Lipidex Inc. (Westfield, NJ). Staurosporine was from Kamiya Biochemical Co. (Thousand Oaks, CA). $\left[\gamma-{ }^{32} \mathrm{P}\right] A T P(3,000 \mathrm{Ci} / \mathrm{mmol})$ and the liquid scintillation cocktail ACS were purchased from Amersham Corp. (Arlington Heights, IL). 1-Stearoyl-2-[arachidonyl-5,6,8,9,11,12,14,15${ }^{3} \mathrm{H}(\mathrm{N})$ )-sn-glycerol was obtained from New England Nuclear (NEN, Boston, MA). D- $\left[{ }^{14} \mathrm{C}(\mathrm{U})\right]$ glucose was either from NEN $(260 \mathrm{mCi} /$ mmol) or ICN Biolchemicals $(320 \mathrm{mCi} / \mathrm{mmol}$, Irvine, CA). Other chemicals were obtained either from Sigma Chemical Co. or from Fisher Scientific (Pittsburgh, PA). All organic solvents were obtained from Burdick and Jackson (Muskegon, MI).

\section{Islet preparation}

Isolation and culture of rat islets. Islets were isolated aseptically from male Sprague-Dawley rats, fed ad lib. as described elsewhere by a procedure involving pancreatic excision, collagenase digestion, and discontinuous Ficoll density gradient separation $(23,24)$. This procedure typically yielded 400 islets/rat. In a typical experiment, islets were isolated from 30 rats. The pooled islets $(\sim 12,000$ islets) were then cultured overnight in four Petri dishes $(\sim 3,000)$ with $2.5 \mathrm{ml}$ of complete CMRL-1066 at $24^{\circ} \mathrm{C}$ under an atmosphere of $95 \%$ air $/ 5 \% \mathrm{CO}_{2}$. Islets cultured in this way exhibit a robust insulin secretory response and enhanced generation of some lipid mediators in response to glucose (23).

Isolation and culture of human islets. Pancreases were removed from four separate life-supported cadavers when other organs were obtained for transplantation. Islets were isolated from the pancreas by methods described elsewhere (25) and were cultured for $3-7 \mathrm{~d}$ at $24^{\circ} \mathrm{C}$ and for $24 \mathrm{~h}$ at $37^{\circ} \mathrm{C}$ just before use under an atmosphere of 95\% air $/ 5 \% \mathrm{CO}_{2}$ in tissue culture medium CMRL-1066 containing $10 \%$ fetal bovine serum, penicillin $(100 \mathrm{U} / \mathrm{ml})$, glutamine $(2 \mathrm{mM})$, and Hepes $(25 \mathrm{mM})$ at $\mathrm{pH} 7.4$.

\section{Measurement of fatty acyl composition of DAG}

Incubation of human islets. For mass measurement experiments, isolated human islets $(\sim 12,000)$ were washed three times in HepesKrebs-3 mM glucose medium, counted (3,000/tube) into $16 \times 100$ $\mathrm{mm}$ acid-washed silanized borosilicate tubes, and preincubated $30 \mathrm{~min}$ with shaking in $0.1 \mathrm{ml}$ of Hepes-Krebs- $3 \mathrm{mM}$ glucose $(25 \mathrm{mM}$ Hepes, pH 7.4, $115 \mathrm{mM} \mathrm{NaCl}, 24 \mathrm{mM} \mathrm{NaHCO}_{3}, 5 \mathrm{mM} \mathrm{KCl}, 2.5 \mathrm{mM} \mathrm{CaCl}_{2}$, $1 \mathrm{mM} \mathrm{MgCl}$, and $0.1 \%$ fatty acid free bovine serum albumin) at $37^{\circ} \mathrm{C}$ under an atmosphere of $95 \%$ air $/ 5 \% \mathrm{CO}_{2}$. The medium was then removed from each tube and replaced with $0.1 \mathrm{ml}$ of fresh HepesKrebs medium supplemented with $17 \mathrm{mM}$ glucose prewarmed to $37^{\circ} \mathrm{C}$. The tubes were then incubated with shaking for $5 \mathrm{~min}$ at $37^{\circ} \mathrm{C}$ under an atmosphere of $95 \%$ air $/ 5 \% \mathrm{CO}_{2}$. At the end of this period 1 $\mathrm{ml}$ of ice-cold methanol was added. The tubes were then chilled for 15 min in a liquid $\mathrm{N}_{2}$ bath and stored at $-70^{\circ} \mathrm{C}$ before extraction.

Extraction of diacylglycerol. Before extraction, tubes for the mass measurement experiments received $0.25 \mathrm{ml}$ of an internal standard solution (100 ng of 1,2-dierucoyl-sn-glycerol) prepared from 1,2-diacyl-sn-glycerol-phosphocholine with Bacillus cereus phospholipase C by methods described elsewhere (13). To each tube was then added $1.25 \mathrm{ml}$ of solvent A. (Solvent A is chloroform/methanol, 1:2, vol/vol.)
The tubes were then sonicated $\left(30 \mathrm{~min}, 4^{\circ} \mathrm{C}\right)$ and vortexed. $\mathrm{CHCl}_{3}$ $(0.66 \mathrm{ml})$ and then $\mathrm{H}_{2} \mathrm{O}(0.66 \mathrm{ml})$ were added, and the tubes were centrifuged ( $3 \mathrm{~min}$ in a table-top centrifuge). The lower (organic) layer was transferred (acid-washed silanized Pasteur pipette) to an acidwashed, silanized $3.5 \mathrm{ml}$ glass vial. The remaining aqueous phase was re-extracted three times with $\mathrm{CHCl}_{3}(1 \mathrm{ml})$. These extracts were combined with the previous organic phase, concentrated under $N_{2}$, and reconstituted in heptane $(0.25 \mathrm{ml})$.

$H P L C$ analysis of DAG. Extracted samples were analyzed by HPLC on a $\mu$ Porasil column $(3.9 \mathrm{~mm} \times 30 \mathrm{~cm}$; Waters Associates, Milford, MA) as described previously (13). Solvent was delivered at a rate of $2 \mathrm{ml} / \mathrm{min}$ with the following program: solvent B (hexane/isopropanol/acetic acid, 100:1:0.01, vol/vol/vol) for $13 \mathrm{~min}$, a linear gradient over $5 \mathrm{~min}$ to solvent $\mathbf{C}$ (hexane/isopropanol/acetic acid, 100:10:0.01, vol/vol/vol), and then solvent $C$ for $7 \mathrm{~min}$. The retention volumes of standard glycerolipids were as follows: triacylglycerol ( 5 $\mathrm{ml}) ; 1,3-$ diacyl-sn-glycerol $(13 \mathrm{ml}) ;$ DAG $(21 \mathrm{ml})$; and monoacylglycerol $(50 \mathrm{ml})$. A 2,3-diacylglycerol is the enantiomer of the corresponding 1,2-diacylglycerol, and therefore these compounds cannot be separated by HPLC or other physical or chemical means unless a second optical center is introduced into the system (e.g., use of a chiral derivatizing reagent, a chiral column, or an enzyme) (26). Phospholipids did not elute in this system, and were retained on a guard column (13), which was changed after every 15 runs. Islet-derived DAG was collected into an acid-washed, silanized 7-ml glass vial, concentrated under $\mathrm{N}_{2}$, and stored in $0.5 \mathrm{ml}$ of heptane before hydrolysis.

Hydrolysis of DAG to free fatty acids. Samples were concentrated to dryness, saponified with $0.2 \mathrm{~N} \mathrm{NaOH}$, and extracted into $\mathrm{CH}_{2} \mathrm{Cl}_{2}$ as described previously (13).

Pentafluorobenzyl esterification of free fatty acids. Fatty acids were converted to pentafluorobenzyl esters with pentafluorobenzyl bromide as described previously (13) and reconstituted in heptane.

Gas chromatography-mass spectrometry. Gas chromatography (GC) was performed on a 5840 gas chromatograph interfaced with a 5988 mass spectrometer (both from Hewlett-Packard Corp., Palo Alto, CA) operated in the negative ion chemical ionization mode (methane source pressure 1 Torr) using a Hewlett-Packard Ultraperformance capillary column $(8 \mathrm{~m}$ length, crosslinked methylsilicone, i.d. 0.31 $\mathrm{mm}$, film thickness $0.17 \mu \mathrm{m}$ ) operated with a Grob-type injector in the splitless mode as previously described (13). The GC oven temperature was programmed from $85^{\circ}$ to $200^{\circ} \mathrm{C}$ at a rate of $30^{\circ} \mathrm{C} / \mathrm{min}$ starting 0.5 min after injection. Selected ions were monitored that corresponded to the $m / z$ [M-181] ions of the fatty acid pentafluorobenzyl ester derivatives. Peak identity was assigned by the mass of the monitored ions and by retention times relative to standard fatty acid pentafluorobenzyl esters. The fatty acid pentafluorobenzyl esters were quantitated relative to erucoylpentafluorobenzyl ester (C22:1 internal standard). Before each set of analyses, a standard curve for each fatty acid pentafluorobenzyl ester was generated. Blank samples derived from incubation medium containing no islets were processed in parallel with islet-derived samples in all experiments, and the observed blank signal was subtracted from the signal of islet-derived samples. Background amounts of fatty acids in blank tubes were $66 \pm 21$ pmol of myristate, $264 \pm 66 \mathrm{pmol}$ of palmitate, $200 \pm 27 \mathrm{pmol}$ of stearate, $79 \pm 11 \mathrm{pmol}$ of oleate, $11 \pm 2$ pmol of linoleate, and $3 \pm 2$ pmol of arachidonate $(n=7)$. Higher blanks were avoided by strictly excluding plasticware from all phases of processing; employing only acid-washed, silanized glassware (including pasteur pipettes); by wearing disposable gloves throughout sample preparation; and by screening solvents and reagents for fatty acid content and employing only those with minimal amounts. Since the total fatty acid background was $\sim 600$ pmol and the fatty acyl content of islet DAG was $\sim 1 \mathrm{pmol} /$ islet, 3,000 islets were employed per condition for diacylglycerol fatty acyl mass measurements to achieve an islet signal fivefold or greater above background.

\section{Measurement of de novo synthesis of DAG from glucose} Incorporation of $\left[{ }^{14} \mathrm{C}\right]$ glucose into islet $D A G$. Isolated rat or human islets were randomly counted (500/tube) into siliconized $13 \times 100$ 
borosilicate tubes, preincubated $30 \mathrm{~min}$ at $37^{\circ} \mathrm{C}$ in $0.1 \mathrm{ml}$ of HepesKrebs-3 mM glucose medium under an atmosphere of $95 \%$ air $/ 5 \%$ $\mathrm{CO}_{2}$. Incubation was initiated by the further addition of $0.1 \mathrm{ml}$ of Hepes-Krebs medium containing $\left[{ }^{14} \mathrm{C}\right]$ glucose to yield a final concentration of 3 or $17 \mathrm{mM}$ glucose with a final specific activity of 58.3 or $11.7 \mathrm{mCi} / \mathrm{mmol}$, respectively. The incubation was continued for $15 \mathrm{~s}$ to $2 \mathrm{~h}$ at $37^{\circ} \mathrm{C}$ in a shaking water bath under an atmosphere of $95 \%$ air $/ 5 \% \mathrm{CO}_{2}$ and terminated by the addition of $1 \mathrm{ml}$ of methanol (previously chilled in an isopropanol/dry ice bath) and $0.1 \mathrm{ml}$ of a $300-\mathrm{mM}$ glucose solution. The tubes were then immersed in a liquid $\mathrm{N}_{2}$ bath for $15 \mathrm{~min}$. In some experiments, islets $(1,000 /$ dish $)$ were incubated 24 or $48 \mathrm{~h}$ in $1 \mathrm{ml}$ of complete CMRL-1066 supplemented with 5.5 or 17 $\mathrm{mM}\left[{ }^{14} \mathrm{C}\right] \mathrm{glucose}$ (final specific activity of 32.2 or $10.7 \mathrm{mCi} / \mathrm{mmol}$, respectively).

Measurement of ${ }^{14} \mathrm{C}$-labeled islet 1,2-diacyl-sn-glycerol. Before extraction, $0.05 \mathrm{ml}$ of internal standard $(30-50,000 \mathrm{cpm}$ of 1-stearoyl-2$\left[{ }^{3} \mathrm{H}_{8}\right]$-arachidonyl-sn-glycerol in heptane) was added to each tube. Extraction of DAG was performed essentially as described above with chloroform/methanol into $10 \mathrm{ml}$ borosilicate silanized conical tubes. The organic phase from the extraction was evaporated under $\mathrm{N}_{2}$ and reconstituted in $0.5 \mathrm{ml}$ of chloroform. Half the sample was then transferred into a clean 10-ml borosilicate silanized conical tube and measured for DAG mass by the enzymatic assay described below. The remaining half of the sample received $10 \mu \mathrm{g}$ each of oleic acid, monoolein, diolein, and triolein to aid in recovery, and was washed three times with $1 \mathrm{ml}$ of $\mathrm{H}_{2} \mathrm{O}$. The organic phase was concentrated with 0.5 $\mathrm{ml}$ of chloroform/methanol (95:5, vol/vol), evaporated under $\mathrm{N}_{2}$, reconstituted in $0.05 \mathrm{ml}$ of diethyl ether, and applied to a $20 \times 20 \mathrm{~cm}$ TLC plate (Analtech silica gel $\mathrm{G}$ channeled plate). The plate was developed in solvent $\mathrm{F}$ (toluene/diethyl ether/ethanol, 35:10:1, vol/vol/vol). Standard unlabeled mono-, di-, and triolein standards were run as controls and were visualized with $I_{2}$ vapor. The spots corresponding to 1,2-diacyl-sn-glycerol were scraped into $20 \mathrm{ml}$ borosilicate scintillation vials. Diethyl ether $(0.5 \mathrm{ml})$ was added $(30 \mathrm{~min})$, followed by liquid scintillation cocktail $(10 \mathrm{ml})$. Vials were counted in a liquid scintillation spectrometer under a double-isotope setting $\left[{ }^{3} \mathrm{H},{ }^{14} \mathrm{C}\right]$. Results were corrected for the recovery of the $\left[{ }^{3} \mathrm{H}\right]$ diacylglycerol internal standard and expressed as picomoles of $\left[{ }^{14} \mathrm{C}\right]$ glucose incorporated into islet DAG (measured as nanomoles on the same sample as described below).

Enzymatic measurement of total DAG mass. Total DAG mass was measured by an enzymatic assay employing diacylglycerol kinase from $E$. coli to phosphorylate DAG to $\left[{ }^{32} \mathrm{P}\right]$ phosphatidic acid, which was then quantitated (27). Several major modifications were incorporated into the original method (27) to obtain more consistent results. Assays were performed in silanized borosilicate conical $10 \mathrm{ml}$ tubes with snap-on plastic caps. Samples (which already contained 30-50,000 cpm of 1-stearoyl-2-[ $\left[{ }^{3} \mathrm{H}_{8}\right]$-arachidonyl-sn-glycerol as an internal standard) were briefly evaporated under $\mathrm{N}_{2}$, immediately reconstituted in $25 \mu$ l of solution $\mathrm{G}$ ( $5 \mathrm{mM}$ cardiolipin, $7.5 \%$ octyl- $\beta$-D-glucoside (recrystallized) in $1 \mathrm{mM}$ DETAPAC, $\mathrm{pH}$ 7.0), vortexed $1 \mathrm{~min}$ (automatic vortexer), sonicated $20 \mathrm{~min}$ in a water bath, and gently mixed for 30 min on a multitube vortexing apparatus. The reaction was initiated by adding $75 \mu \mathrm{l}$ of a $\left.{ }^{32} \mathrm{P}\right] \mathrm{ATP}$ mixture. The final composition of the incubation mixture $(100 \mu \mathrm{l})$ was: $50 \mathrm{mM}$ imidazole, $\mathrm{pH} 6.6,50 \mathrm{mM}$ $\mathrm{NaCl}, 12.5 \mathrm{mM} \mathrm{MgCl}{ }_{2}, 1 \mathrm{mM}$ EGTA, $1 \mathrm{mM}\left[\gamma^{-32} \mathrm{P}\right]$ ATP $(25 \mu \mathrm{Ci}), 2$ $\mathrm{mM}$ dithiothreitol, $20 \mathrm{mU}$ of diacylglycerol kinase, $1.875 \%$ octyl- $\beta$-Dglucoside, $1.25 \mathrm{mM}$ cardiolipin, $0.25 \mathrm{mM}$ DETAPAC. The mixture was preincubated for $30 \mathrm{~min}$ at room temperature before addition to assay samples to reduce the blank value. After addition of the [ $\left.{ }^{32} \mathrm{P}\right] \mathrm{ATP}$ mixture, assay tubes were vigorously vortexed for $1 \mathrm{~min}$ and incubated for $30 \mathrm{~min}$ at room temperature with continuous gentle mixing. The reaction was terminated by addition of $3 \mathrm{ml}$ of chloroform/methanol $(1: 2, \mathrm{vol} / \mathrm{vol})$. Unlabeled phosphatidic acid $(20 \mu \mathrm{g})$ and lysophosphatidic acid $(20 \mu \mathrm{g})$ were added to each tube as carriers. This was followed by addition of $1 \mathrm{M} \mathrm{NaCl}(0.75 \mathrm{ml})$, vortexing $(1 \mathrm{~min})$, addition of $\mathrm{CHCl}_{3}(1 \mathrm{ml})$, addition of $1 \mathrm{M} \mathrm{NaCl}(1 \mathrm{ml})$ and vortexing $(1 \mathrm{~min})$ Samples were then centrifuged ( $5 \mathrm{~min}, 800 \mathrm{~g}$ ), and the upper aqueous phase was discarded. The lower organic phase was washed twice with $1 \%$ perchloric acid $(2 \mathrm{ml})$. These acid aqueous washes were discarded after centrifugation. The lower (organic phase) was evaporated under $\mathrm{N}_{2}$, concentrated with $0.5 \mathrm{ml}$ of chloroform/methanol (95:5, vol/vol), evaporated under $\mathrm{N}_{2}$, reconstituted in $0.05 \mathrm{ml}$ of chloroform/methanol $(95: 5, \mathrm{vol} / \mathrm{vol})$, and applied to a channeled Whatman LK-6 plate (Whatman, Inc., Clifton, NJ) (pre-run in acetone and heat-activated 30 min at $80^{\circ} \mathrm{C}$ ). The plate was developed in solvent $\mathrm{H}$ (chloroform/ methanol/acetic acid, 65:15:5, vol/vol/vol). Standard unlabeled phosphatidic acid, lysophosphatidic acid, and diacylglycerol were run as controls and were visualized with $\mathrm{I}_{2}$ vapor. The $\left[{ }^{32} \mathrm{P}\right]$ phosphatidic acid spots were visualized by autoradiography, scraped into 20 - $\mathrm{ml}$ borosilicate scintillation vials and incubated overnight with $1 \mathrm{ml}$ of methanol/acetic acid (80:20, vol/vol). Liquid scintillation cocktail (ACS, 10 $\mathrm{ml}$ ) was then added, and the samples were counted in a liquid scintillation spectrometer under a double-isotope setting $\left[{ }^{3} \mathrm{H},{ }^{32} \mathrm{P}\right]$. Results were corrected for the recovery of $\left[{ }^{3} \mathrm{H}\right]$ diacylglycerol and expressed as nanomoles of DAG. This was determined from the specific activity of $\left[\gamma-{ }^{32} \mathrm{P}\right] \mathrm{ATP}$. Unlabeled ATP stocks were standardized enzymatically (28).

\section{Measurement of insulin secretion}

Islet perifusion. 300 isolated human islets were placed in each chamber of a dual or quadruple chamber perifusion apparatus perifused with Hepes-Krebs-3 mM glucose for $30 \mathrm{~min}$ at $37^{\circ} \mathrm{C}$ as described $(28,29)$. The glucose concentration was then increased to $8 \mathrm{mM}$ in both chambers, and $200 \mu \mathrm{M}$ of 1-oleoyl-2-acetyl-sn-glycerol in $0.4 \%$ DMSO was simultaneously added to the medium of the experimental but not the control chamber. The insulin content of aliquots of the perifusion effluent was measured by radioimmunoassay (23). Insulin secretion from islets perifused first with $3 \mathrm{mM}$ glucose and then with $28 \mathrm{mM}$ glucose in the absence of OAG was determined in a similar manner.

Insulin secretion during static incubations. Isolated human islets were randomly counted (30/tube) into $10 \times 75 \mathrm{~mm}$ borosilicate tubes and preincubated for $30 \mathrm{~min}$ at $37^{\circ} \mathrm{C}$ with shaking in $0.2 \mathrm{ml}$ of HepesKrebs-3 mM glucose media under an atmosphere of $95 \%$ air $/ 5 \% \mathrm{CO}_{2}$. The medium was then removed from each tube and replaced with fresh medium $(0.2 \mathrm{ml})$ supplemented with the appropriate agonist. Islets were then incubated with shaking at $37^{\circ} \mathrm{C}$ for varied time periods. At the end of the incubation, the supernatant was removed and placed on ice. Serial dilutions were prepared and stored at $-20^{\circ} \mathrm{C}$ before determination of their insulin content by radioimmunoassay (23).

\section{Measurement of protein kinase $C$ activity}

Isolated human islets $(10-16,000)$ were homogenized in 0.35 to $0.6 \mathrm{ml}$ of ice-cold TES buffer ( $25 \mathrm{mM}$ TES-NaOH pH 7.4, 1 mM EGTA, 0.5 mM DTT, $1 \mathrm{mM}$ phenylmethane sulfonylfluoride, $100 \mu \mathrm{g} / \mathrm{ml}$ leupeptin) using a Dounce (Teflon/glass) homogenizer (13 passes). Samples were centrifuged in an ultracentrifuge (Beckman Instruments, Inc., Richmond, CA) $\left(155,000 \mathrm{~g}_{\mathrm{av}}, 60 \mathrm{~min}, 4^{\circ} \mathrm{C}\right)$. The supernatant (cytosolic fraction) was assayed for protein kinase $\mathrm{C}$ activity by measuring the incorporation of $\left.{ }^{32} \mathrm{P}\right] \mathrm{PO}_{4}$ from $\left[\gamma^{32} \mathrm{P}\right] \mathrm{ATP}$ into histone III-S at $30^{\circ} \mathrm{C}$ as described (17). In brief, the assay was performed in $100 \mu \mathrm{l}$ of solution I ( $100 \mathrm{mM}$ TES- $\mathrm{NaOH}$ pH 7.4, $5 \mathrm{mM} \mathrm{MgCl}{ }_{2}, 1 \mathrm{mM}$ EGTA, $400 \mu \mathrm{g} / \mathrm{ml}$ histone III-S, $1.3 \mathrm{mM} \mathrm{Ca}^{2+}$, free $\mathrm{Ca}^{2+}$ concentration $=300$ $\mu \mathrm{M}, 125 \mu \mathrm{g} / \mathrm{ml}$ phosphatidylserine, and $2.4 \mu \mathrm{g} / \mathrm{ml}$ diolein). After a preincubation period of $2 \mathrm{~min}$, the reaction was initiated by the addition of $10 \mu \mathrm{l}$ of $\left[\gamma-{ }^{32} \mathrm{P}\right] \mathrm{ATP}$ (final concentration $20 \mu \mathrm{M}, 1.4 \mu \mathrm{Ci} /$ tube). At $30 \mathrm{~s}, 50 \mu \mathrm{l}$ of stop buffer ( $186 \mathrm{mM}$ Tris- $\mathrm{HCl}$ pH 6.7, $9 \mathrm{mM}$ SDS, 6 $\mathrm{mM}$ 2-mercaptoethanol, $15 \%$ glycerol) was added, and protein was denatured by boiling for $2 \mathrm{~min}$. Phosphorylated histone bands were separated from endogenous proteins by SDS-PAGE in $12 \%$ gels. After visualization by Coomassie blue staining, the three histone bands of highest molecular weight (accounting for $95 \%$ of histone radioactivity) were excised from the gel and their ${ }^{32} \mathrm{P}$ content determined by liquid scintillation spectrometry (17). Protein kinase $\mathrm{C}$ activity was calculated after subtracting the basal activity reflected by ${ }^{32} \mathrm{Pi}$-incorporation into 
histone in the presence of $\mathrm{Ca}^{2+}$ and absence of phosphatidylserine and diolein.

\section{Results}

Influence of exogenous diacylglycerol on insulin secretion from human islets. Isolated human pancreatic islets perifused with medium containing $3 \mathrm{mM}$ glucose for $30 \mathrm{~min}$ exhibited a basal insulin secretory rate of $0.1 \mu \mathrm{U} /$ islet per min as illustrated in Fig. 1. Increasing the medium glucose concentration to $8 \mathrm{mM}$ resulted in a brisk first phase of insulin secretion with a mean peak secretory rate of $0.55 \pm 0.23 \mu \mathrm{U} /$ islet per min. A maximal mean glucose-induced insulin secretory rate of $1.27 \mu \mathrm{U} /$ islet per min was achieved with $28 \mathrm{mM}$ glucose. The second, sustained phase of insulin secretion in response to $8 \mathrm{mM}$ glucose was $0.23 \pm 0.09 \mu \mathrm{U} /$ islet per min. This was similar to the corresponding second phase secretory rate with $28 \mathrm{mM}$ glucose and was $\sim 2.5$-fold greater than the basal secretory rate at $3 \mathrm{mM}$ glucose. Addition of the cell-permeant diacylglycerol, 1-oleoyl-2-acetyl-sn-glycerol (OAG), at a concentration of 200 $\mu \mathrm{M}$ to perifusion medium containing $8 \mathrm{mM}$ glucose, resulted in an increase in the first phase secretory rate to $1.06 \pm 0.16$ $\mu \mathrm{U} /$ islet per min and in an increase in the second phase secretory rate to $0.76 \pm 0.08 \mu \mathrm{U} /$ islet per $\min (P<0.005$ vs. $8 \mathrm{mM}$ glucose alone) (Fig. 1). The first phase secretory response to

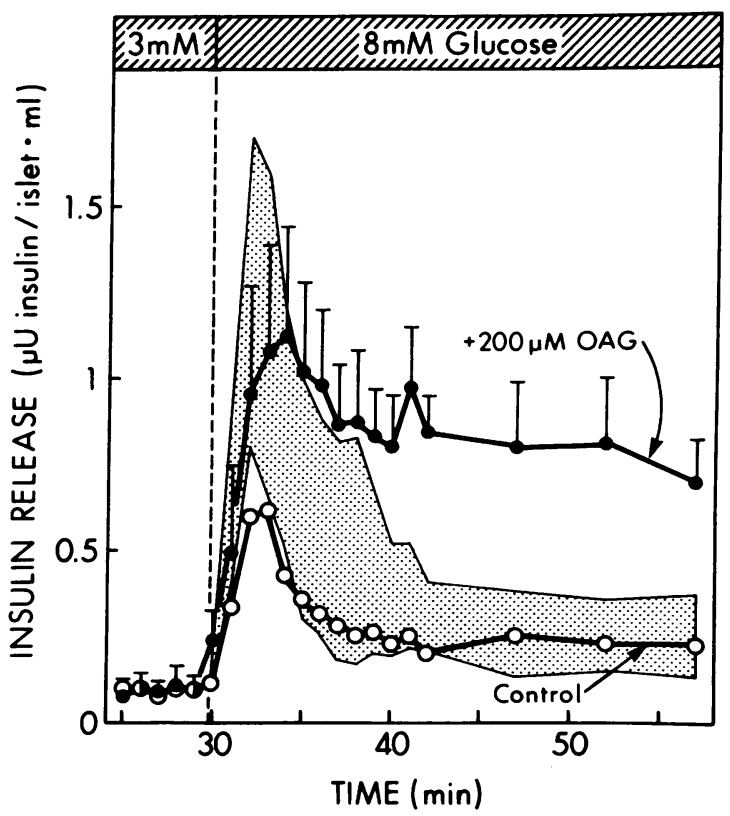

Figure 1. Effects of exogenous diacylglycerol on insulin secretion by perifused human islets. Isolated human islets (300/chamber) were placed in a perifusion chamber and perifused for $30 \mathrm{~min}$ at $37^{\circ} \mathrm{C}$ with Hepes-Krebs medium (25 mM Hepes pH 7.4, $115 \mathrm{mM} \mathrm{NaCl}$, $24 \mathrm{mM} \mathrm{NaHCO}_{3}, 5 \mathrm{mM} \mathrm{KCl}, 2.5 \mathrm{mM} \mathrm{CaCl}_{2}, 1 \mathrm{mM} \mathrm{MgCl}$ and $0.1 \%$ fatty acid-free bovine serum albumin) supplemented with 3 $\mathrm{mM}$ glucose. Perifusion was then continued for $30 \mathrm{~min}$ in the presence of Hepes-Krebs medium supplemented with either $8 \mathrm{mM}$ glucose (with (•) or without (0) $200 \mu \mathrm{M}$ of 1-oleoyl-2-acetyl-sn-glycerol (OAG) in $0.4 \%$ DMSO or $28 \mathrm{mM}$ glucose (shaded area). $1 \mathrm{ml} / \mathrm{min}$ fraction were collected and assayed for insulin release by radioimmunoassay. Results are shown as the mean $\pm \mathrm{SE}$ of insulin release $(\mu \mathrm{U}$ insulin/islet per $\mathrm{min}$ ) for control (0) or OAG-stimulated $(\bullet, n=4)$ islets. The range of insulin release in response to $28 \mathrm{mM}$ glucose is indicated by the shaded area.
OAG plus $8 \mathrm{mM}$ glucose was essentially equivalent to that achieved with a maximally stimulatory concentration of glucose $(28 \mathrm{mM})$, and the second phase response was 3.2-fold greater than that induced by glucose alone. OAG did not induce insulin secretion from isolated islets incubated in medium containing either 0 or $3 \mathrm{mM}$ glucose (not shown). These experiments indicate that exogenous diacylglycerol amplifies the insulin secretory response to glucose by isolated human pancreatic islets, as has previously been reported for rodent islets $(13,14)$.

Endogenous DAG in human islets. To determine the quantity and fatty acyl substituents of any endogenous DAG in isolated human pancreatic islets, neutral lipids were extracted from the islets in the presence of an internal standard diacylglycerol (1,2-dierucoyl-sn-glycerol). The diacylglycerols in the extract were then isolated by HPLC, saponified to their constituent fatty acids, converted to their pentafluorbenzyl ester (PFBE) derivatives, and analyzed by GC negative ionchemical ionization (NICI) mass spectrometry (MS). The identity of endogenous fatty acyl substituents of human islet DAG was determined by GC retention time and characteristic ions on MS, and the quantity of these materials was determined relative to the known amount of erucate (C22:1) in the internal standard, as illustrated in Fig. 2. Isolated human islets were found to contain clearly detectable amounts of DAG, and, as illustrated in Fig. 3, this material contained the fatty acyl substituents palmitate, stearate, oleate, linoleate, and arachidonate in approximately equal abundance. This is, in general, similar to the fatty acyl composition of diacylglycerols isolated from rodent islets, except that the relative abundance of linoleate is substantially greater in the human material. The total quantity of saponifiable long-chain fatty acyl substituents in human islet DAG was $\sim 1.3 \mathrm{pmol} /$ islet. This would correspond to a DAG mass of $0.65 \mathrm{pmol} / \mathrm{islet}$ because of the stoichiometry of $2 \mathrm{~mol}$ of fatty acyl moieties per mole of glycerol. If the islet intracellular volume is $3 \mathrm{nl}$ (7), dividing the DAG mass by that volume yields a concentration of $216 \mu \mathrm{M}$. In principle, then, endogenous islet DAG levels may approximate the concentrations of exogenous diacylglycerol required to influence insulin secretion.

De novo synthesis of $D A G$ from glucose in islets. When isolated islets were incubated with uniformly labeled $\left[{ }^{14} \mathrm{C}\right] \mathrm{glu}-$ cose for various periods and the neutral lipids were coextracted with a $\left[{ }^{3} \mathrm{H}\right]$ diacylglycerol internal standard and analyzed by TLC, incorporation of $\left[{ }^{14} \mathrm{C}\right]$ from $\left[{ }^{14} \mathrm{C}\right]$ glucose into islet DAG could readily be demonstrated (Fig. 4). Accumulation of DAG synthesized de novo from $\left[{ }^{14} \mathrm{C}\right]$ glucose was dependent on the concentration of $\left[{ }^{14} \mathrm{C}\right]$ glucose and on the incubation time. A significant difference between islet $\left[{ }^{14} \mathrm{C}\right] \mathrm{DAG}$ content at basal $(3 \mathrm{mM})$ and stimulatory $(17 \mathrm{mM})$ glucose concentrations was first observed at $60 \mathrm{~s}$ of incubation $(P<0.05$, Fig. $4, A$ and $B)$.

De novo synthesis of diacylglycerol did, however, continue to occur in a glucose concentration and time-dependent manner at longer incubation times. At a basal glucose concentration (3 mM), de novo synthesis of DAG from glucose was linear for at least $2 \mathrm{~h}$ with a rate of incorporation of glucose into DAG of $0.2 \mathrm{pmol}$ glucose $/ \mathrm{nmol} \mathrm{DAG} / \mathrm{min}(r=0.984)$. This rate of incorporation increased to $0.4 \mathrm{pmol}$ glucose $/ \mathrm{nmol}$ $\mathrm{DAG} / \mathrm{min}(r=1.000)$ at the stimulatory glucose concentration of $17 \mathrm{mM}$ (Fig. $4 C$ ).

The magnitude of de novo synthesis of DAG stimulated by glucose was similar in human and rat islets (Fig. 4 B). Al- 


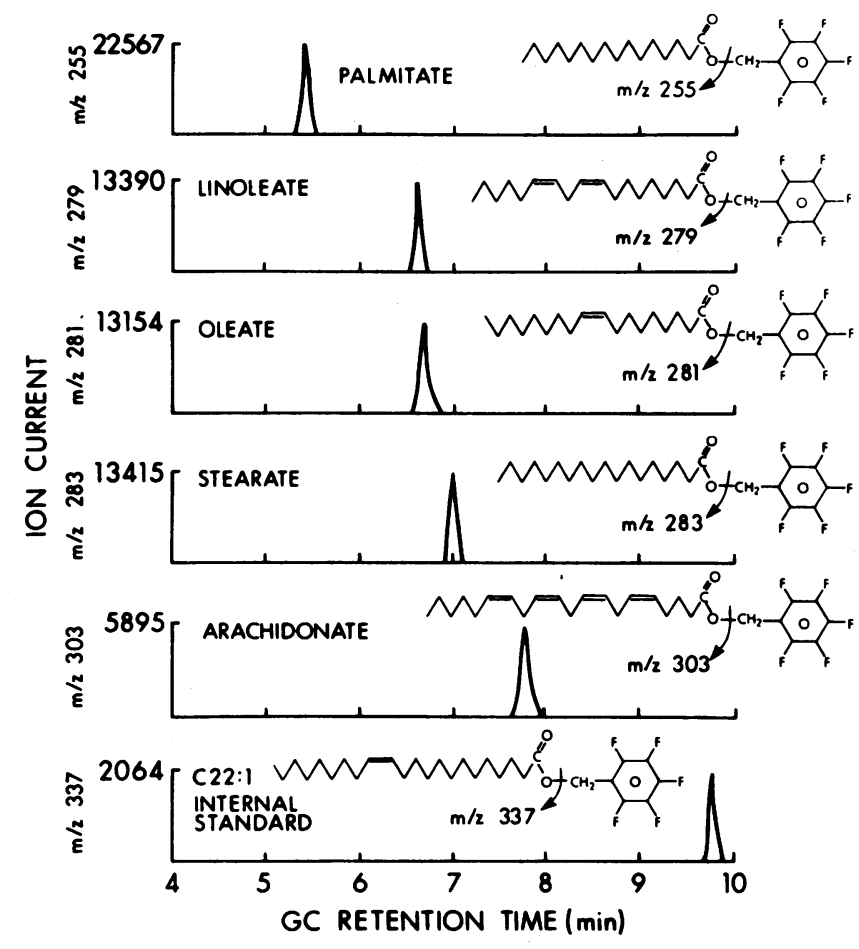

Figure 2. Gas chromatographic-negative ion-chemical ionizationmass spectrometric analysis of the fatty acyl content of human islet DAG. Incubations of human islets $(3,000 /$ tube $)$ were terminated by addition of $100 \mathrm{ng}$ of the internal standard (1,2-dierucoyl-sn-glycerol) in $0.25 \mathrm{ml}$ of $\mathrm{CHCl}_{3} /$ methanol (1:2). Neutral lipids were extracted as described in Methods. Islet DAG was isolated by normal phase HPLC and then saponified to its constituent free fatty acids. The free fatty acids were converted to their pentafluorobenzyl (PFBE) esters and reconstituted in heptane. $2 \mu \mathrm{l}$ of this solution were injected into a Hewlett-Packard 5840 gas chromatograph interfaced with a Hewlett-Packard 5988 mass spectrometer operated in the negative ion-(methane) chemical ionization mode as described in Methods. Selected ions were monitored that corresponded to the molecular weight of the fatty acid PFBE derivatives minus 181, reflecting the loss of the pentafluorobenzyl moiety, as illustrated by the structural diagrams of the PFBE-fatty acids in the figure.

though these experiments clearly demonstrated de novo synthesis of DAG from glucose by both rat and human islets, the contribution from this process to the total islet DAG mass was quite small during incubation times of $20 \mathrm{~min}$ or less (Fig. 4, $A$ and $B$ ). At $5 \mathrm{~min}$ of incubation, the difference between glucose-stimulated and control islets in $\left[{ }^{14} \mathrm{C}\right]$ glucose incorporation into DAG amounted to only $0.99 \pm 0.29$ pmol of $\left[{ }^{14} \mathrm{C}\right] \mathrm{glu}$ cose carbon skeleton for each nanomole of DAG. The corresponding figure for human islets was $0.62 \pm 0.22 \mathrm{pmol}$ glucose/nmol DAG. These observations suggest that only about one to two parts per thousand of islet DAG arose from de novo synthesis from glucose during the period when glucose induces insulin secretion. At incubation times of 1 and $2 \mathrm{~d}$ with a stimulatory concentration $(17 \mathrm{mM})$ of $\left[{ }^{14} \mathrm{C}\right]$ glucose, de novo synthesis contributed a substantial fraction of total islet DAG (Fig. 4 D). At $2 \mathrm{~d}, 170 \pm 17$ pmol $\left[{ }^{14} \mathrm{C}\right]$ glucose had been incorporated per nanomole of islet diacylglycerol. This is $34 \%$ of the theoretically possible $500 \mathrm{pmol}$ of $\left[{ }^{14} \mathrm{C}\right]$ glucose/ nmol DAG.

These experiments therefore indicate that de novo synthesis of DAG is a minor process during acute stimulation with

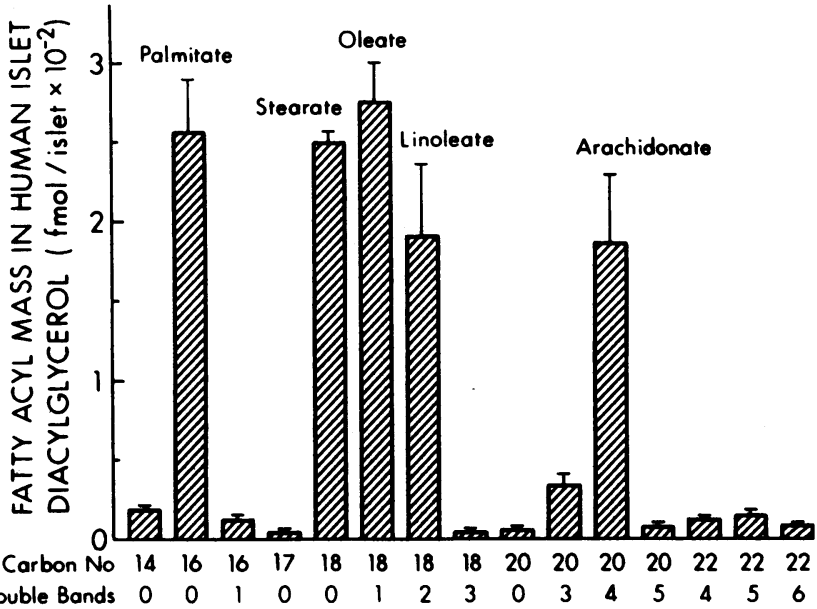

Figure 3. Fatty acyl composition of DAG from human islets. Isolated human islets were cultured overnight at $37^{\circ} \mathrm{C}$ in complete CMRL-1066 medium as described in Methods. 3,000 islets were counted into each tube and preincubated for $30 \mathrm{~min}$ at $37^{\circ} \mathrm{C}$ in Hepes-Krebs medium supplemented with $3 \mathrm{mM}$ glucose. The medium was then removed and replaced with fresh medium, and the islets were incubated for $5 \mathrm{~min}$ at $37^{\circ} \mathrm{C}$. The fatty acyl composition of islet-derived DAG was determined by gas chromatographic-negative ion-chemical ionization-mass spectrometric analysis as shown in Fig. 2. Results are shown as the mean \pm SE of the fatty acyl mass in human islet DAG expressed as fmol/islet $(n=4)$.

glucose and is unlikely to cause an increase in total islet DAG content on the time scale involved in stimulus secretion coupling. At much longer incubation times, however, de novo synthesis is a significant contributor to the total islet DAG content.

Enzymatic measurement of total islet DAG content. To measure the total islet content of DAG, a modification of the method of Preis et al. (27) was employed. This method involves extraction of neutral lipids and addition of exogenous diglyceride kinase and $\left[\gamma_{-}{ }^{32} \mathrm{P}\right] \mathrm{ATP}$ to convert diglyceride to $\left[{ }^{32} \mathrm{P}\right]$ phosphatidic acid. $\left[{ }^{32} \mathrm{P}\right]$ phosphatidic acid is then isolated by TLC and quantitated by liquid scintillation counting. Modifications of the original procedure that were found necessary to achieve satisfactory measurements of the amounts of DAG in islets included: (a) a much longer period of sonication to achieve quantitative solubilization of the DAG; $(b)$ preincubation of the diglyceride kinase with unlabeled ATP to reduce the blank value of the preparations; $(c)$ addition of unlabeled phosphatidic acid as a carrier to reduce adsorptive losses of low level samples; and $(d)$ inclusion of 1-stearoyl-2-[ $\left.{ }^{3} \mathrm{H}_{8}\right]$ arachidonyl-sn-glycerol as an internal standard to correct for losses during extraction and chromatography and to improve the precision of the measurements. The ${ }^{3} \mathrm{H}$ from the internal standard and the ${ }^{32} \mathrm{P}$ from the reaction product were distinguished by dual channel liquid scintillation counting. Under these conditions, the blank value of the assay was $40 \mathrm{pmol}$ and the precision was $7 \%$. The assay was linear from $100 \mathrm{pmol}$ to the low nanomolar range.

Effect of glucose on islet DAG content. Basal islet DAG content as measured by this enzymatic assay was $\sim 1 \mathrm{pmol} /$ islet, as illustrated in Fig. $5 \mathrm{~A}$. Addition of $B$. cereus phospholipase $\mathrm{C}$ to suspensions of intact islets in incubation buffer resulted in a sevenfold rise in their DAG content (Fig. $5 \mathrm{~A}$ ). Increasing the glucose content of the incubation buffer in- 

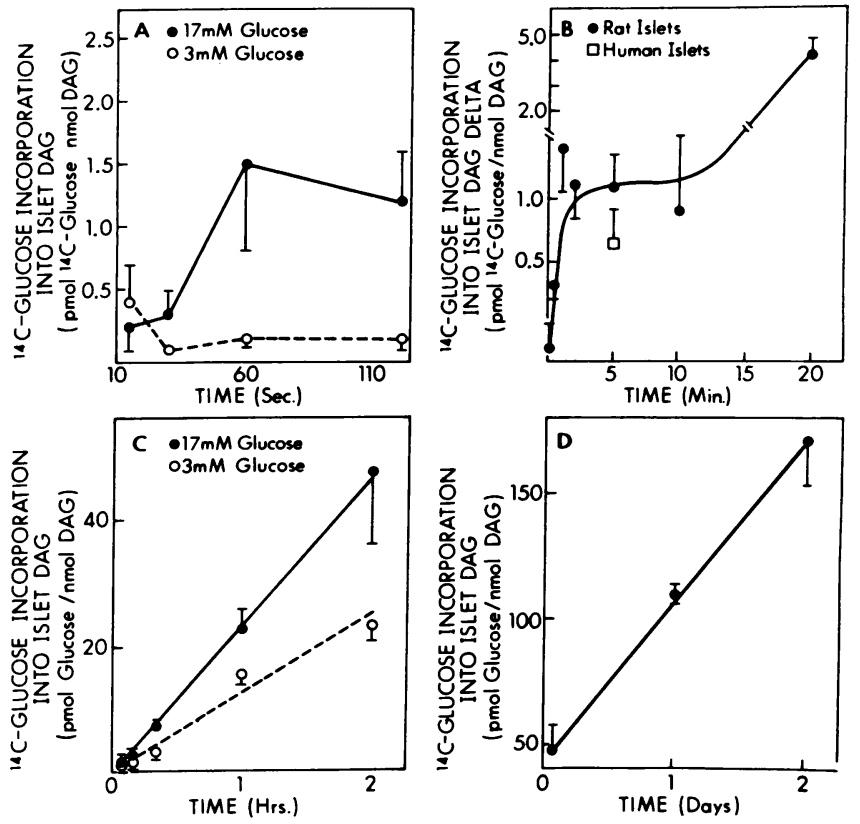

Figure 4. De novo synthesis of DAG from $\left[{ }^{14} \mathrm{C}\right]$ glucose by rat and human islets. Isolated rat or human islets $(500 /$ tube) were preincubated for $30 \mathrm{~min}$ at $37^{\circ} \mathrm{C}$ in $0.1 \mathrm{ml}$ of Hepes-Krebs- $3 \mathrm{mM}$ glucose medium. Incubation was initiated by the addition of $0.1 \mathrm{ml}$ of Hepes-Krebs medium containing $\left[{ }^{14} \mathrm{C}\right]$ glucose to yield a final concentration of 3 or $17 \mathrm{mM}$ glucose (final specific activity of 58.3 or $11.7 \mathrm{mCi} / \mathrm{mmol}$, respectively). Neutral lipids were then extracted in the presence of 1-stearoyl-2- $\left[{ }^{3} \mathrm{H}_{8}\right]$ arachidonyl-sn-glycerol as an internal standard. The $\left[{ }^{14} \mathrm{C}\right]$ content of islet-derived DAG was determined after TLC isolation, and the DAG mass was measured as described in Fig. 5. (A) Early (seconds) time-course of de novo synthesis. Results are shown as the mean $\pm \mathrm{SE}$ of pmol of $\left[{ }^{14} \mathrm{C}\right]$ glucose incorporated per nmol of DAG at $17 \mathrm{mM}(\bullet)$ or $3 \mathrm{mM}(0)$ glucose from 4 to 10 observations per condition in rat islets. $(B)$ De novo synthesis in rat and human islets. Results are expressed as the difference between the incorporation of $\left[{ }^{14} \mathrm{C}\right]$ glucose into DAG (pmol glucose/nmol DAG) at stimulatory (17 mM) and basal ( $3 \mathrm{mM})$ glucose concentrations from 2 to 10 observations per condition for rat $(\bullet)$ and human () islets. $(C)$ Rate of de novo synthesis. Results are shown as the mean \pm SE of pmol of $\left[{ }^{14} \mathrm{C}\right]$ glucose incorporated into nmol of DAG at $17 \mathrm{mM}(\bullet)$ or $3 \mathrm{mM}(0)$ glucose from three to nine observations per condition. Least-square regression analysis indicates a rate of incorporation of glucose into DAG at $3 \mathrm{mM}$ glucose of $0.2 \mathrm{pmol}$ glucose/ $\mathrm{nmol}$ DAG per $\min (r=0.984$, dashed line $)$ and at $17 \mathrm{mM}$ glucose of $0.4 \mathrm{pmol}$ glucose $/ \mathrm{nmol} \mathrm{DAG} / \mathrm{min}(r=1.000$, solid line $)$. (D) Long term de novo synthesis. Rat islets were incubated as described above with $17 \mathrm{mM}\left[{ }^{14} \mathrm{C}\right]$ glucose for periods of $2 \mathrm{~h}, 1 \mathrm{~d}$, or $2 \mathrm{~d}$. The $\left[{ }^{14} \mathrm{C}\right]$ content of islet DAG was then determined as described above.

duced an increase in insulin secretion that was clearly demonstrable by $2 \mathrm{~min}$ and continued to rise progressively at 5 and 10 min (Fig. $5 \mathrm{~B}$ ). Under these conditions, however, glucose did not influence the DAG content of rat islets at any time point between $15 \mathrm{~s}$ and $20 \mathrm{~min}$ (Fig. $5 \mathrm{C}$ ). Glucose also failed to influence the DAG content of human islets as measured by the enzymatic assay or by GC-NICI-MS quantitation of the DAG fatty acyl content (Fig. $5 \mathrm{D}$ ). There was an excellent correspondence between the mass of DAG in human islets measured by the enzymatic assay $(0.75 \mathrm{pmol} /$ islet $)$ and the fatty acyl content of the DAG measured by GC-NICI-MS (1.34 pmol/islet) in view of the expected 1:2 stoichiometry (Fig. 5 $D$ ). Analysis of the individual fatty acyl substituents of DAG
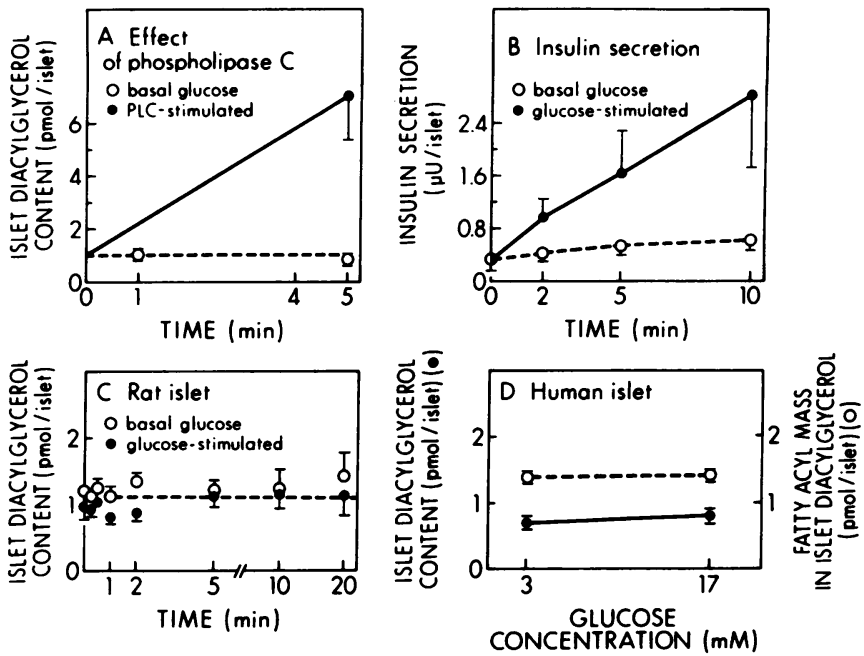

Figure 5. Effect of glucose on the DAG content of rat and human islets. Isolated rat or human islets were incubated as described in Fig. 4. The DAG was extracted and assayed as described in Methods. $(A)$ Effect of phospholipase C. Exogenous phospholipase C (PLC) from $B$. cereus $(20 \mathrm{U})$ was added to the incubation medium of rat islets. $(B)$ Insulin secretion by rat islets. $(C)$ DAG content of rat islets. Results are shown as the mean \pm SE of the DAG content (pmol/islet) determined enzymatically from 3 to 11 observations per condition. (D) Comparison of the DAG content of human islets determined by gas chromatography-mass spectrometry and by enzymatic assay. Results are shown as the mean \pm SE of the DAG content measured as the fatty acyl mass in DAG by gas chromatography-mass spectrometry (O) as described in Fig. 2 and with the diacylglycerol kinase assay (๑) described in Methods.

from human islets revealed no differences between resting and glucose-stimulated islets (not shown). After long-term incubation (1-2 d) with $17 \mathrm{mM}$ glucose, however, there was an increase in rat islet DAG content, as measured by the enzymatic assay of $200 \pm 66 \mathrm{fmol} /$ islet compared to islets incubated at 5.5 $\mathrm{mM}$ glucose.

Effect of staurosporine and sphingosine on protein kinase $C$ activity and glucose-induced insulin secretion from human islets. To explore the possibility that glucose might induce a local, but functionally important, increase in DAG in human islets, the influence of compounds that suppress the activation of protein kinase $\mathrm{C}$ by diacylglycerol was examined. We have previously demonstrated that staurosporine (30) completely inhibits rat islet protein kinase $C$ at a concentration of $10 \mathrm{nM}$ in cell-free systems and that, at a concentration of $100 \mathrm{nM}$, staurosporine suppresses both phorbol ester and glucose-induced insulin secretion from rat islets (17). As shown in Fig. 6 $A$, staurosporine ( $100 \mathrm{nM}$ ) inhibits protein kinase $C$ activity in human islets with a concentration dependence similar to that observed in rat islets. Staurosporine (100 nM) did not, however, significantly influence basal or glucose-induced insulin secretion from human islets (Fig. 6 B). Similar results were obtained with a second protein kinase $C$ inhibitor, sphingosine (31). Sphingosine failed to inhibit basal or glucose-induced insulin secretion from human islets at any concentration from $25 \mu \mathrm{M}$ (Fig. $6 C$ ) to $100 \mu \mathrm{M}$ (not shown).

\section{Discussion}

This study establishes that exogenous diacylglycerol amplifies glucose-induced insulin secretion from isolated human pan- 


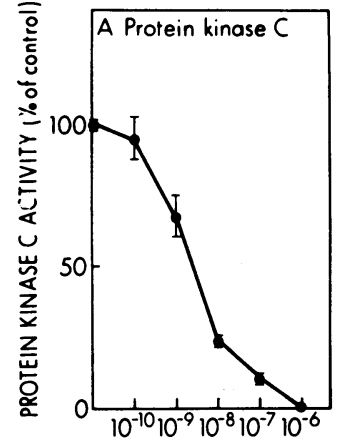

STAUROSPORINE (M)

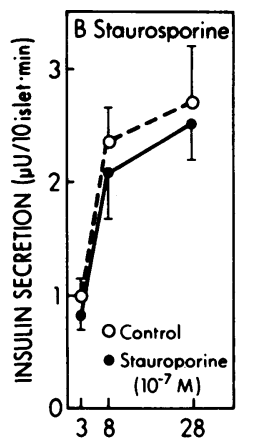

GLUCOSE $(\mathrm{m} M)$

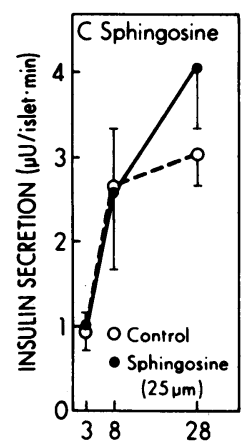

GLUCOSE (mM)
Figure 6. Effects of staurosporine and sphingosine on protein kinase $\mathrm{C}$ activity and insulin secretion by human islets. $(A)$ Staurosporine inhibition of protein kinase $\mathrm{C}$ activity. Protein kinase $\mathrm{C}$ activity was measured in the cytosol as described in Methods. Results are shown as the mean $\pm \mathrm{SE}$ percent of control protein kinase $\mathrm{C}$ activity in the presence of varied concentrations of staurosporine $(n=3)$. (B) Effect of staurosporine on glucose-induced insulin secretion. Results are shown as the mean $\pm \mathrm{SE}$ of insulin secretion ( $\mu \mathrm{U}$ insulin/10 islets/ $\mathrm{min}$ ) by control $(\mathrm{O})$ and staurosporine-treated $\left(\bullet, 10^{-7} \mathrm{M}\right)$ islets at 3 , 8 , or $28 \mathrm{mM}$ glucose (21 observations per condition). (C) Effect of sphingosine on glucose-induced insulin secretion. Results are shown as the mean $\pm \mathrm{SE}$ of insulin secretion ( $\mu \mathrm{U}$ insulin/islet per min) by control (o) and sphingosine-treated $(\bullet, 25 \mu \mathrm{M})$ islets at 3,8 , or 28 $\mathrm{mM}$ glucose (four observations per condition).

creatic islets and that human islets contain endogenous DAG in amounts sufficient in principle to achieve intracellular concentrations within the range required to influence insulin secretion. De novo synthesis of DAG from glucose has also been demonstrated here to occur in pancreatic islets isolated from rats and from humans. This process has been determined, however, to be a quantitatively minor contributor to the total islet content of DAG during acute stimulation with glucose, and concentrations of glucose sufficient to stimulate insulin secretion have been shown not to influence the DAG content of rat islets, as determined by an enzymatic assay, or of human islets, as determined both enzymatically and by mass spectrometric methods, within $20 \mathrm{~min}$. Two compounds that prevent diacylglycerol-induced activation of protein kinase C, staurosporine (30) and sphingosine (31), have also been shown not to influence glucose-induced insulin secretion from human islets. These findings argue strongly against the hypothesis that de novo synthesis of DAG from glucose participates in the induction of insulin secretion by glucose from human pancreatic islets.

The possibility that de novo synthesis of DAG from glucose participated in signal transduction in islets was appealing because it would have provided a long-sought link between the metabolism of glucose and the induction of insulin secretion $(1,4,6)$. Several groups had demonstrated qualitatively that rodent islets did in fact convert $\left[{ }^{14} \mathrm{C}\right]$ glucose to $\left[{ }^{14} \mathrm{C}\right]$ diacylglycerol $(11,18-21)$, and we have here demonstrated that this process also occurs in human islets. Ours is the first study of which we are aware to determine the quantitative significance and the detailed time-course of this phenomenon. From our study it is apparent that, on the time scale in which glucose induces insulin secretion, metabolism of glucose to DAG does not make a quantitatively significant contribution to total islet
DAG mass. The de novo synthesis of DAG from glucose is therefore unlikely to participate in short-term signal transduction in islets. This study also demonstrates, however, that conversion of glucose to DAG continues to occur in a glucoseconcentration and time-dependent fashion for at least $2 \mathrm{~d}$. De novo synthesis of DAG from glucose becomes a quantitatively significant process upon prolonged stimulation with glucose. During $48 \mathrm{~h}$ at $17 \mathrm{mM}$ glucose, $34 \%$ of total accumulated islet DAG arose from this pathway, and there was a concomitant increase in DAG mass. Elevated diacylglycerol levels have recently been reported in other tissues subject to diabetic complications $(32,33)$.

The potential involvement of diacylglycerol-induced activation of protein kinase $C$ in insulin secretion from rodent islets has been an area of continuing debate $(16,17,34-37)$. With rodent islets, several inhibitors of protein kinase $C$ have been reported to suppress insulin secretion induced by phorbol esters and by glucose at comparable concentrations $(16,17)$. Depletion of rodent islet protein kinase $\mathrm{C}$ content by prolonged phorbol ester preexposure, however, does not influence glucose-induced insulin secretion (38), and glucose does not induce a cytosol to membrane translocation of rodent islet protein kinase $C$ activity $(17,38)$. Such translocation often accompanies protein kinase $\mathrm{C}$ activation and is clearly demonstrable in phorbol ester-stimulated islets $(17,38)$. These data suggest that diacylglycerol-induced activation of protein kinase $\mathrm{C}$ does not play an obligatory role in glucose-induced insulin secretion from rodent islets. The lack of influence of pharmacologic inhibitors of protein kinase $\mathrm{C}$ on glucose-induced insulin secretion observed here suggests that this is also the case with human islets.

The failure of glucose to cause translocation of rat islet protein kinase $\mathrm{C}$ had heretofore been puzzling because glucose does induce the accumulation of a palmitate-rich DAG in rat islets $(11,13)$. This phenomenon is somewhat easier to understand in view of the present finding that glucose does not cause an increase in the total DAG mass in rat islets measured enzymatically, although the finding itself was unexpected. This may reflect glucose-induced 2,3-diacyl-sn-glycerol accumulation via triacylglycerol hydrolysis (26). This compound is not recognized by diglyceride kinase (27) and does not activate protein kinase $C(26)$ but is not distinguished from DAG by saponification-based GC/MS methods (13). An alternative explanation is that glucose causes an increased turnover of rat islet DAG, with a resultant remodeling of its fatty acid composition, without a change in the absolute level of DAG. The high ambient levels of palmitate in sample blanks may also have complicated its quantitation in the trace quantities derived from islet diacylglycerol in a more variable manner than previously recognized. Determination of the alkylacyl-diglyceride $(39,40)$ content of rat islets would also be of interest in this regard. Such molecules contain a single saponifiable fatty acid residue, rather than the two such residues contained in diacyl-diglycerides, and saponification-based methods will therefore underestimate their contribution to the total molar quantity of diglyceride. How readily individual species of alkylacyl-diglycerides are phosphorylated by diglyceride kinase is also unknown (27). Unfortunately, direct measurement of alkylacyl-diglycerides in the amount likely to occur in rat islets presents a difficult technical problem (39). In any case, shortterm exposure to stimulatory concentrations of glucose does not induce accumulation of a palmitate-rich DAG in human 
islets and does not influence the total DAG content of either human or rat islets.

The influence of exogenous diacylglycerol on insulin secretion from human islets and the close correspondence between the concentration required for this effect and the islets content of endogenous diacylglycerol also suggests that DAG could play a permissive role in insulin secretion, even under conditions where DAG levels are not acutely regulated. The activities of several enzymes and the physical properties of phospholipid membranes are now recognized to be influenced by diacylglycerols in a protein kinase $\mathrm{C}$-independent manner (41-45). Diacylglycerol accumulation and/or protein kinase $C$ activation may also play an important role in the action on islets of certain noncarbohydrate insulin secretagogues, such as cholinergic agonists $(8,11,46)$.

\section{Acknowledgments}

The excellent technical assistance of Wendy Conrad-Kessel, Robert Seabold, Thomas Stump, Connie Marshall, and Joan Fink is gratefully acknowledged. Jane Huth is due special thanks for her expert preparation of the manuscript.

These studies were supported by grants from the U.S. Public Health Service (grants R01-DK-34388, K04-DK-01553, R01-DK-06181, S10-RR-04693, and RR-00954), from the Council for Tobacco Research (grant 2364), and from the Juvenile Diabetes Foundation International (grant 188471).

\section{References}

1. Blackgard, W. G. 1986. Insulin deficiency. In Clinical Diabetes Mellitus. J. K. Davidson, editor. Thieme Inc., New York. 54-63.

2. Malaisse, W. J., A. Sener, A. Herchulez, and J. C. Hutton. 1979. Insulin release: The fuel hypothesis. Metab. Clin. Exp. 28:373-386.

3. Hedeskov, C. J. 1980. Mechanism of glucose-induced insulin secretion. Physiol. Rev. 60:442-509.

4. Ashcroft, S. H. J. 1980. Glucoreceptor mechanisms and the control of insulin release and biosynthesis. Diabetologia. 18:5-15.

5. Wollheim, C. B., and G. W. G. Scharp. 1981. Regulation of insulin release by calcium. Physiol. Rev. 61:914-973.

6. Meglasson, M. D., and F. Matschinsky. 1986. Pancreatic islet glucose metabolism and regulation of insulin secretion. Diabetes/ Metab. Rev. 2:163-214.

7. Turk, J., B. A. Wolf, and M. L. McDaniel. 1987. The role of phospholipid-derived mediators including arachidonic acid, its metabolites, and inositol trisphosphate and of intracellular calcium in glucose-induced insulin secretion by pancreatic islets. Prog. Lipid Res. 26:125-181.

8. Prentki, M., and F. Matschinsky. 1987. Calcium, cyclic AMP, and phospholipid-derived messengers in coupling mechanism of insulin secretion. Physiol. Rev. 67:1185-1248.

9. Bonner-Weir, S. 1988. Pancreatic islets: Morphology, organization, and physiological implications. In Insulin Secretion. B. Draznin, S. Melmed, and D. LeRoith, editors. Alan R. Liss, Inc., New York. $1-12$.

10. Pfeiffer, M. A., J. B. Halter, and D. J. Porte. 1981. Insulin secretion in diabetes mellitus. Am. J. Med. 70:579-588.

11. Peter-Riesch, B., M. Fahti, W. Schlegel, and C. B. Wollheim. 1988. Glucose and carbachol generate 1,2-diacylglycerols by different mechanisms in pancreatic islets. J. Clin. Invest. 81:1154-1161.

12. Wollheim, C. B., M. J. Dunne, B. Peter-Riesch, M. J. Bruzzone, T. Possan, and O. H. Peterson. 1988. Activators of protein kinase C depolarize insulin-secreting cells by closing potassium channels. EMBO (Eur. Mol. Biol. Organ.) J. 7:2443-2449.
13. Wolf, B. A., R. A. Easom, J. H. Hughes, M. L. McDaniel, and J. Turk. 1989. Secretagogue-induced diacylglycerol accumulation in isolated pancreatic islets. Mass spectrometric characterization of the fatty acyl content indicates multiple mechanisms of generation. Biochemistry. 28:4291-4301.

14. Malaisse, W. J., M. E. Dunlop, P. C. Mathias, F. MalaisseLagae, and A. Sener. 1985. Stimulation of protein kinase $C$ and insulin release by 1-oleoyl-2-acetyl-glycerol. Eur. J. Biochem. 149:23-27.

15. Zawalich, W., C. Brown, and H. Rasmussen. 1983. Insulin secretion: combined effects of phorbol ester and A23187. Biochem. Biophys. Res. Commun. 117:448-455.

16. Stutchfield, J., P. M. Jones, and S. I. Howell. 1986. The effects of polymyxin $B$, a protein kinase $C$ inhibitor, on insulin secretion from intact and permeabilized islets of Langerhans. Biochem. Biophys. Res. Commun. 136:1001-1006.

17. Easom, R. A., J. H. Hughes, M. Landt, B. A. Wolf, J. Turk, and M. L. McDaniel. 1989. Comparison of effects of phorobol esters and glucose on protein kinase $C$ activation and insulin secretion in pancreatic islets. Biochem. J. In press.

18. Dunlop, M. D., and R. G. Larkins. 1985. Pancreatic islets synthesize phospholipids de novo from glucose via acyl-dihydroxyacetone phosphate. Biochem. Biophys. Res. Commun. 132:467-473.

19. Dunlop, M., and R. G. Larkins. 1985. Presence of membraneassociated phosphatidate phosphohydrolase activity in cultured islets and its stimulation by glucose. FEBS (Fed. Eur. Biochem. Soc.) Lett. 193:231-235.

20. Vara, E., and J. Tamarit-Rodriguez. 1986. Glucose stimulation of insulin secretion in islets of fed and starved rats and its dependence on lipid metabolism. Metab. Clin. Exp. 35:266-271.

21. Farese, R. V., P. E. DiMarco, D. E. Barnes, M. A. Sabir, R. E. Larson, J. S. Davis, and A. D. Morrison. 1986. Rapid glucose-dependent increases in phosphatidic acid and phosphoinositides in rat pancreatic islets. Endocrinology. 118:1498-1503.

22. Matschinsky, F. M., A. M. Ghosh, M. D. Meglasson, M. Prentki, V. June, and D. von Allman. 1986. Metabolism concomitants in pure, pancreatic beta cells during glucose-stimulated insulin secretion. J. Biol. Chem. 261:14057-14051.

23. Turk, J., J. R. Colca, N. Kotagal, and M. L. McDaniel. 1984. Arachidonic acid metabolism in isolated pancreatic islets II. The influence of glucose and inhibitors of arachidonate metabolism on insulin secretion and metabolite synthesis. Biochim. Biophys. Acta. 794:125136.

24. McDaniel, M. L., J. R. Colca, N. Kotagal, and P. E. Lacy. 1983. A subcellular fractionation approach for studying insulin release mechanism and calcium metabolism in islets of Langerhans. Methods Enzymol. 98:182-200.

25. Ricordi, C., P. E. Lacy, E. H. Finke, B. J. Olack, and D. W. Scharp. 1988. Automated method for isolation of human pancreatic islets. Diabetes. 37:413-420.

26. Söling, H.-D., E. Machado-DeDomenach, J. Kleineke, and W. Fest. 1987. Early effects of $\beta$-adrenergic and muscarinic secretagogues on lipid and phospholipid metabolism in guinea pig parotid acinar cells. Stimulation of 2,3-sn-diacylglycerol formation by isoproterenol. J. Biol. Chem. 262:16786-16792.

27. Preis, J. E., C. R. Loomis, R. M. Bell, and J. E. Niedel. 1987. Quantitative measurement of sn-1,2-diacylglycerol. Methods Enzymol. 141:294-300.

28. Wolf, B. A., J. Turk, W. R. Sherman, and M. L. McDaniel. 1986. Intracellular $\mathrm{Ca}^{2+}$ mobilization by arachidonic acid. Comparison with myo-inositol 1,4,5-trisphosphate in isolated pancreatic islets. J. Biol. Chem. 261:3501-3511.

29. Lacy, P. E., M. M. Walker, and C. J. Fink. 1972. Perifusion of isolated rats in vitro: participation of the microtubular system in the biphasic release of insulin. Diabetes. 21:987-998.

30. Tamanoki, T., H. Nomoto, I. Takahashi, Y. Kato, M. Morimoto, and F. Tomita. 1986. Staurosporine is a potent, specific inhibitor of protein kinase C. Biochem. Biophys. Res. Commun. 135:397402. 
31. Hannun, Y. A., C. S. Greenberg, and R. M. Bell. 1987. Sphingosine inhibition of agonist-dependent secretion and activation of human platelets implies that protein kinase $\mathrm{c}$ is a necessary and common event of the signal transduction pathways. J. Biol. Chem. 262:13620-13626.

32. Lee, T.-S., L. C. MacGregor, S. J. H. Fluharty, and G. L. King. 1989. Differential regulation of protein kinase $\mathrm{C}$ and $(\mathrm{Na}, \mathrm{K})$-adenosine trisphosphatase activities by elevated glucose levels in retinal capillary endothelial cells. J. Clin. Invest. 83:90-94.

33. Okumbra, K., N. Akiyama, H. Hashimoto, K. Ogawa, and T. Satake. 1988. Alteration of 1,2-diacylglycerol content in myocardium from diabetic rats. Diabetes. 37:1168-1172.

34. Metz, S. A. 1988. Is protein kinase $C$ required for physiologic insulin release? Diabetes. 37:3-7.

35. Metz, S. A. 1988. Exogenous arachidonic acid promotes insulin release from intact or permeabilized islets by dual mechanisms. Putative activation of calcium mobilization and protein kinase C. Diabetes. 37:1455-1469.

36. Jones, P. M., J. Stutchfield, and S. L. Howell. 1986. Effects of calcium and a phorbol ester on insulin secretion from islets of Langerhans permeabilized by high-voltage discharge. FEBS (Fed. Eur. Biochem. Soc.) Lett. 191:102-106.

37. Hii, C. S., P. M. Jones, S. J. Persaud, and S. L. Howell. 1987. A re-assessment of the role of protein kinase $C$ in glucose-stimulated insulin secretion. Biochem. J. 246:489-493.

38. Persaud, S. J., P. M. Jones, D. Sugden, and S. L. Howell. 1988. Translocation of protein kinase $C$ in rat islets of Langerhans. Effects of a phorbol ester, carbachol and glucose. FEBS (Fed. Eur. Biochem. Soc.) Lett. 245:80-84.
39. Sugiura, T., M. Nakajima, N. Sekiguchi, Y. Nakagawa, and K. Waku. 1983. Different fatty chain composition of alkenylacyl, alkylacyl, and diacyl phospholipids in rabbit alveolar macrophages: high amounts of arachidonic acid in ether phospholipids. Lipids. 18:125129.

40. Daniel, L. W., G. W. Small, and J. D. Schmitt. 1988. Alkyllinked diglycerides inhibit protein kinase $\mathrm{C}$ activation by diacylglycerols. Biochem. Biophys. Res. Commun. 151:291-297.

41. Kolesnick, R. N. 1987. 1,2-diacylglycerols but not phorbol esters stimulate sphingomyelin hydrolysis in $\mathbf{G H}_{3}$ pituitary cells. $J$. Biol. Chem. 262:16759-16762.

42. Burch, R. M. 1988. Diacylglycerol stimulates phospholipase $A_{2}$ from Swiss 3T3 fibroblasts. FEBS (Fed. Eur. Biochem. Soc.) Lett. 234:283-286.

43. Goppelt-Strube, M., H.-J. Pfannkuche, D. Gemsa, and K. Resch. 1987. The diacylglycerols dioctanoylglycerol and oleoylacetylglycerol enhance prostaglandin synthesis by inhibition of the lysophosphatide acyltransferase. Biochem. J. 247:773-777.

44. Restrepo, D., D. J. Kozoday, and P. A. Knauf. 1989. Synthetic diacylglycerols trigger an increase of intracellular free calcium in promyelocytic HL 60 cells. J. Biol. Chem. 264:776-881.

45. Epand, R. M. 1985. Diacylglycerols, lysolecithin, or hydrocarbons markedly alter the bilayer to hexagonal phase transition temperature of phosphatidylethanolamines. Biochemistry. 24:7092-7095.

46. Yamatani, T., T. Chiba, S. Kadowaki, R. Hishikawa, A. Yamaguchi, T. Inui, T. Fujita, and S. Kawazu. 1988. Dual action of protein kinase $\mathrm{C}$ activation in the regulation of insulin release by muscarinic agonist from rat insulinoma cell line (RINr). Endocrinology. 122:2826-2832. 